\title{
Variation in Total Soil Organic Carbon Stocks in Relation to Some Land Use Systems in the Bamenda Highlands, Cameroon
}

\author{
Christian Tegha Kum ${ }^{1 *}$, Aaron Suh Tening², Martin Ngwabie ${ }^{1}$, Cornelius Tsamo1 \\ ${ }^{1}$ Department of Agricultural and Environmental Engineering, College of Technology, The University of Bamenda, \\ Bamenda, Cameroon \\ ${ }^{2}$ Department of Agronomic and Applied Molecular Sciences, Faculty of Agriculture and Veterinary Medicine, University of Buea, \\ Buea, Cameroon \\ Email: ^teghechrist@yahoo.com
}

How to cite this paper: Kum, C. T., Tening, A. S., Ngwabie, M., \& Tsamo, C. (2021). Variation in Total Soil Organic Carbon Stocks in Relation to Some Land Use Systems in the Bamenda Highlands, Cameroon. Journal of Geoscience and Environment Protection, 9, 150-165.

https://doi.org/10.4236/gep.2021.99009

Received: August 24, 2021

Accepted: September 26, 2021

Published: September 29, 2021

Copyright $\odot 2021$ by author(s) and Scientific Research Publishing Inc. This work is licensed under the Creative Commons Attribution International License (CC BY 4.0).

http://creativecommons.org/licenses/by/4.0/

(c) (i) Open Access

\begin{abstract}
Climate change and food security are among the pressing challenges facing humanity in the $21^{\text {st }}$ century. Soil organic carbon (SOC) stocks, total nitrogen (TN), texture, and bulk density (BD) are important soil properties, which control climate change. Three land use systems (smallholder farmlands, grazing lands, and forest lands) that coexist in the Bamenda Highlands (BH) influence ecosystem services and induce soil degradation with the loss of SOC. The objective of this study was to evaluate the variation of SOC and some soil physicochemical properties as affected by the three land use systems (LUS). A total of 21 composite soil samples collected from 7 microclimatic zones of $\mathrm{BH}$ following "S" shape plots to the depth of $0-30 \mathrm{~cm}$, were analysed for moisture content (MC), SOC, TN, BD, available phosphorus (Av.P), $\mathrm{pH}$ and texture. The results revealed that grazing land had the lowest mean sand content (40.79 \pm 4.07$)$. Mean MC, TN and SOC $(\%)$ content were significantly higher $(p<0.05)$ in forest land than those in the grazing land and smallholder farmlands. Conversely, BD and Av.P were significantly higher $(p<0.05)$ in smallholder farmlands than grazing and forest lands probably due to different litter accumulation and agricultural practices. Moisture content and TN revealed positive significant correlations $(p<$ 0.05 ) with SOC, while $\mathrm{BD}$ and Av.P revealed negative significant correlations ( $p$ $<0.05)$. Mean SOC density in smallholder farmlands $(132.91 \pm 9.48 \mathrm{tC} / \mathrm{ha})$ was the lowest among the three land use types. Losses in $\mathrm{CO}_{2}$ equivalence, as a result of land use change from forest lands to smallholder farmlands were $137.33 \mathrm{t} / \mathrm{ha}$ while that from grazing lands to smallholder farmlands were $109.13 \mathrm{t} / \mathrm{ha}$. Total organic carbon (TOC) stocks differed significantly $(p<0.05)$ from smallholder farmlands $(10.73 \mathrm{Mt})$ to forest lands $(91.13 \mathrm{Mt})$. A sustainable farming technique that enhances SOC sequestration and minimizes soil $\mathrm{CO}_{2}$ emissions is
\end{abstract}


therefore recommended to replace tillage ridges formation commonly practiced by smallholder farmers.

\section{Keywords}

Soil, Soil Organic Carbon, Land Use Systems, Bamenda Highlands, Soil $\mathrm{CO}_{2}$ Emissions

\section{Introduction}

The two most pressing and interlinked challenges facing human and environmental sustainability in this 21 st century are climate change and food security (Godfray et al., 2011). According to IPCC (2001), the accumulation of Carbon dioxide $\left(\mathrm{CO}_{2}\right)$ in the atmosphere is the leading factor attributed to be the basis of climate change. Efforts to achieve food security through intensification of agricultural activities contribute heavily to the accumulation of $\mathrm{CO}_{2}$ in the atmosphere leading to the global climate change challenge. Climate change on the other hand, inflicts negative impacts on agricultural production. Carbon sequestration by oceans, plants and soils is the most economic viable option to limit the rising levels of $\mathrm{CO}_{2}$ in the atmosphere (FAO, 2001). Land use change may induce changes in the biological, physical, chemical, and hydrological properties of soils. Conversion of terrestrial ecosystems such as forest and natural savannah for cultivation, grazing, and settlement generally results in a decrease in soil organic matter (SOM) (FAO, 2001). Yao et al. (2010) stated that soils can differ in physical properties based on land use types. These physical properties are crucial to root growth, infiltration, water and nutrient holding capacity (Zhang \& Shangguan, 2016).

The livelihood of rural people in sub-Saharan Africa remains largely dependent on natural resources (Roe et al., 2009). Even so, natural as well as anthropogenic factors such as rainfall, temperature, farming practices and grazing, exert pressure on these natural resources leading to spatial and temporal scale changes on a landscape and bio-physico-chemical nature of the soil. In Cameroon, about $80 \%$ of the population is engaged in biodiversity related activities, most of which impact positively on the family revenue or on a greater extent, the national economy and foreign trade. Over $70 \%$ of the Cameroon population is engaged in agriculture (MINADER, 2015).

Conventional agricultural land use practices alter the soil organic carbon (SOC) availability, $\mathrm{pH}$, nutrient availability and other chemical properties (Cookson et al., 2007) which, in turn, alter soil microbial community structure and function, thus, altering productivity. Farming practices in the Bamenda highlands include; complete overturn tillage with ridges formation, tillage without ridges formation, no till, and strip tillage. About $98 \%$ of smallholder famers in the Bamenda highlands are involved in complete overturn tillage with ridges formation. This tillage system also involves; slash and burn, burning of crop residues within tilled ridges, and heavy applications of agrochemicals such as 
mineral fertilizers and pesticides. These practices lead to reduction in the soil biodiversity, soil organic carbon storage, and increase in irreversible erosion of soil (Schiavon et al., 1995). Maize being the most staple crop in the Bamenda highlands is cultivated mainly through complete overturn tillage with or without formation of ridges.

Furthermore, Vermeulen et al. (2012) reported that agriculture was directly responsible for $14 \%$ of global annual greenhouse gas (GHG) emissions with an additional $17 \%$ of GHG emissions from conversion of forest lands to agricultural lands. Developing countries including Cameroon, accounted for about 3/4 of direct emissions and are expected to be the most rapidly growing emission sources in the future $(\mathrm{FAO}, 2011) . \mathrm{CO}_{2}$, methane $\left(\mathrm{CH}_{4}\right)$ and nitrous oxide $\left(\mathrm{N}_{2} \mathrm{O}\right)$ were identified as key GHGs that contribute towards global warming at $60 \%$, $15 \%$ and 5\%, respectively and are the gases most emitted from agricultural fields as a result of tillage and agricultural inputs practices (Watson et al., 1996). The concentrations of $\mathrm{CO}_{2}, \mathrm{CH}_{4}$ and $\mathrm{N}_{2} \mathrm{O}$ in the atmosphere increase at $0.4 \%, 0.3 \%$ and $0.22 \%$ per year, respectively (Battle et al., 1996).

Although a consent exists that the resource use efficiency, climate change and food security challenges will exacerbate under the conventional agricultural practices, little is predicted about the magnitude of these adverse change over time in developing countries. This probably hinders the development and implementation of both essential and appropriate adaptation and mitigation measures/policies to increase the resilience of agricultural production systems. Quantification of SOC from soil is therefore needed for global modelling studies in the context of climate change (Li et al., 1997) and ecosystem modification to be implemented. Global, regional and local estimates of SOC from staple crop fields vary greatly with the assumptions made on the importance of different factors affecting the emissions. Hence, the need to estimate SOC stocks as a result of land use change before the deployment of any system that is aimed at facilitating climate change and food security predictions round the world. The main staple foods in the average African diet are cereals and the most common cereal in Cameroon is Maize (Zea mays). However, in spite of availability of a number of cereal varieties with improved yield potential, the productivity of staple cereal crops remains low, around $1 \mathrm{t} / \mathrm{ha}$ (WDR, 2007). Every year there is thus a critical shortage of cereals in many smallholder households, leading to high grain prices, hunger, undernourishment and widespread poverty. Therefore, the need to estimate SOC stocks from conventional cereal farming practices in Africa cannot be overemphasized.

This study was therefore aimed at estimating a baseline of total SOC stocks in smallholder farms, grazing and forest lands in the $\mathrm{BH}$ to aid future modelling of SOC stocks, and the development and implementation of appropriate mitigation and adaptation policies.

\section{Materials and Methods}

\subsection{Study Area}

This study was carried out in the Bamenda highlands $(1,740,000$ ha) of North 
West Cameroon located between latitudes $5^{\circ} 45^{\prime} \mathrm{N}$ and $9^{\circ} 9^{\prime} \mathrm{N}$ and longitudes $9^{\circ} 13^{\prime} \mathrm{E}$ and $11^{\circ} 13^{\prime} \mathrm{E}$ (Tellen \& Yerima, 2018; Manu et al., 2014). The BH has a great variation in topography from depressions of less than $400 \mathrm{~m}$ to mountains slightly more than $3000 \mathrm{~m}$ above sea level (Tellen \& Yerima, 2018). The region counts 1,968,600 people in 2015 with a density of 114 persons $/ \mathrm{km}^{2}$. The Bamenda highlands comprise seven administrative divisions, of less than $200 \mathrm{~km}$ apart (Ndoh et al., 2016) (Figure 1). These highlands experience an equatorial climate of the Cameroon type with two major seasons: A long, wet season of eight months (March to October), and a short, dry season of four months from November to March (Tume et al., 2020). The average annual rainfall and temperature is $2675.2 \mathrm{~mm}$ and $22.3^{\circ} \mathrm{C}$ respectively (Azinwi et al., 2018). The soils of the Bamenda highlands are predominantly ferralsols (Yerima \& Van Ranst, 2005). Erosion, resulting from the topographic nature and torrential rainfall, is a major obstacle to sustaining the soil fertility.

\subsection{Land Use (LU) Map}

The subset of Landsat 7 (ETM+) scenes (band 1, 2, 3, 4, 5 and 7) with cloud cover less than five percent were obtained from 2020 Landsat ETM satellite images of the Bamenda Highlands and used for this study. These images are freely available from the United States Geological Survey (USGS) obtained using Earth Explorer (https://dds.cr.usgs.gov/). The images were geometrically corrected using 21 ground control points (GCPs), obtained from the field survey using the GPS device.

A supervised classification using maximum likelihood classification system with overall accuracy of $87.14 \%$ and kappa coefficient of 0.89 , was conducted to classify the Landsat $7(\mathrm{ETM}+)$ image using the spectral signatures from the training data. Means and variances of classes were used to estimate probabilities and check on variability of brightness in each class. The classified images were smoothened twice with a $3 \times 3$-majority rule filter. Various forest lands, grazing lands, and farmland areas were extracted and from the classified image and added to give the total area for each of these classes. The tools used were; ENVI 4.7 and QGIS software, camara, and Global Positioning System (GPS).

\subsection{Experimental Design}

The main land use types in the $\mathrm{BH}$ were studied from the land use map and three typical land use systems (LUS) (smallholder farmlands, grazing land, and forestland) were selected. Detailed investigation was carried out to ascertain the history and current situation of the cultivated lands. The entire $\mathrm{BH}$ was divided into 7 microclimatic zones namely; cold, cloudy, misty, cool misty, warm, wet, and variable (warm wet, sunny) according to Tume et al. (2020). The smallholder farms were ploughed, fertilized and planted with mixed crops every year under conventional tillage and ridges formation for more than ten years. The grazing 


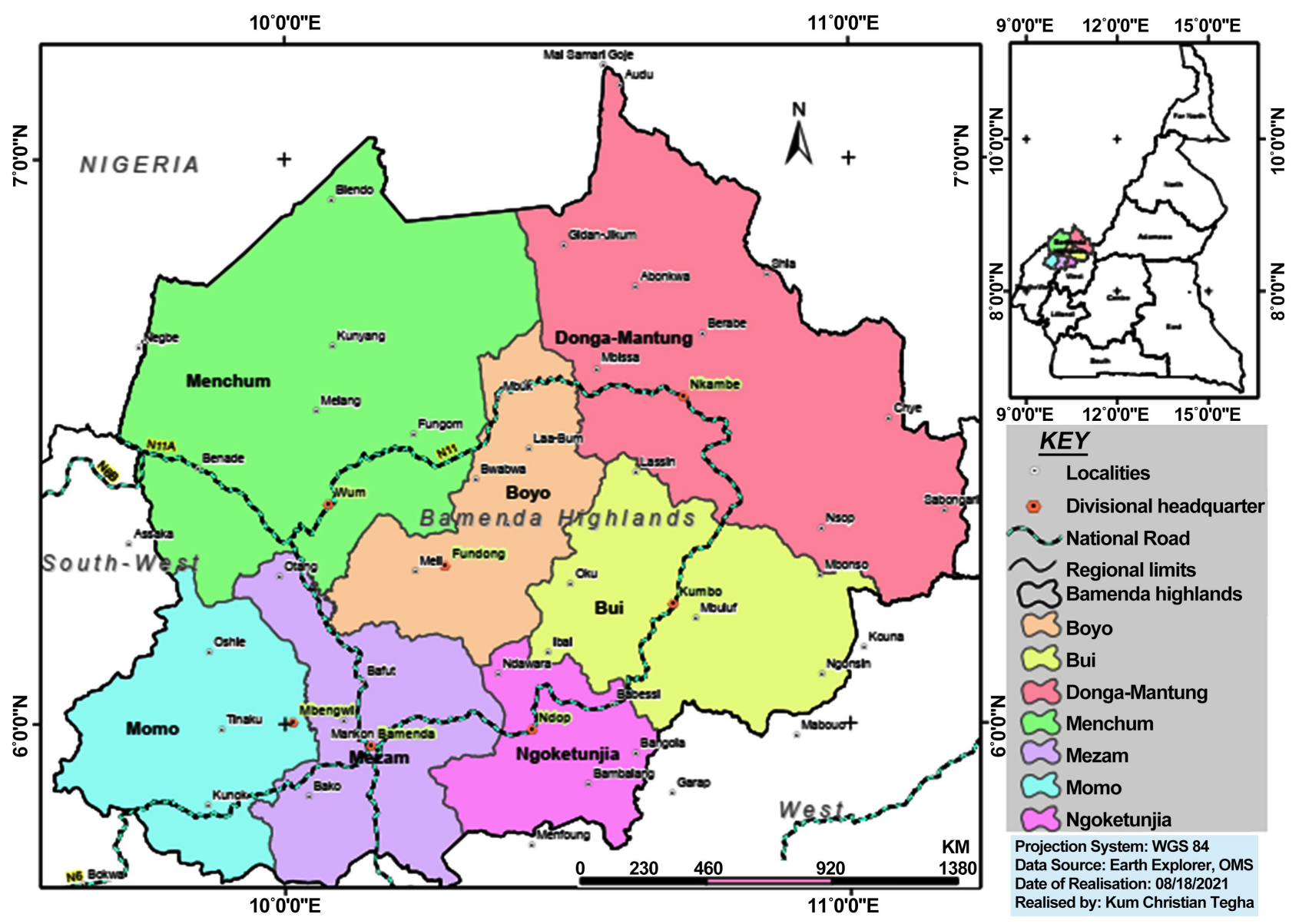

Figure 1. Map showing the location of Bamenda Highlands, Cameroon.

lands are natural savannah regularly grazed with cattle. The three land use types had similar geographic conditions, belonged to the same microclimatic zones with probably the same parent materials.

Fieldwork was carried out in November 2020. Three sampling plots of $50 \times 50$ m were identified using the method of Kum \& Yinda (2016) for each of the three LUSs in the seven microclimatic zones of the BH. Soil samples were collected with the aid of a soil hand auger at soil depth of $30 \mathrm{~cm}$. The sampling plots of each LUS in a microclimatic zone were distributed according to an "S" shape to cover vertical and horizontal variations (Jiao et al., 2020). At each sampling plot, three soil samples were collected, following a diagonal transect across the plot and bulked to give a homogenous sample for that plot. The three bulked soil samples from the sampling plots of each of the LUSs (smallholder farmlands, grazing lands, and forest lands) gave a total of 63 soil samples for the entire $\mathrm{BH}$.

\subsection{Soil Sampling and Analysis}

The collected soil samples were air-dried for two weeks, ground in a ceramic mortar using a pestle, and sieved through a $2 \mathrm{~mm}$ sieve. The three soil samples from a land use system within the same microclimatic zone were thoroughly 
mixed to give a composite sample for that LUS in that microclimatic zone. A total of 21 composite samples (7 for each of the three LUS) were sent for analysis at the Laboratory of Soil Analysis and Chemistry of the Environment (LABASCE) of the Faculty of Agronomy and Agricultural Sciences, University of Dschang, Cameroon. The particle size distribution and textural class were determined using Robinson's pipette method (FAO, 2006). The SOC was measured by the Walkley-Black method (1934). The $\mathrm{pH}$ (Potassium chloride (KCl)) was determined according to McLean (1982) in a soil/Potasium Chloride ratio of 1:2.5. Total nitrogen and available phosphorous were measured using Kjeldahl and concentrated nitric acid methods respectively (Bremner \& Mulvaney, 1982; Olsen \& Sommers, 1980). Sample for soil bulk density and moisture content analysis were collected using a metal core. The volume of the core was determined using Equation (1):

$$
V=\pi r^{2} h\left(\mathrm{~cm}^{3}\right)
$$

where $V=$ volume of core $\left(\mathrm{cm}^{3}\right) ; \pi=3.14 ; r=$ radius = diameter $/ 2(\mathrm{~cm}) ;$ and $h=$ height $(\mathrm{cm})$.

The soil moisture content and bulk density were determined by noting the difference in weight of fresh soil samples and oven dried soil samples at temperatures of $105^{\circ} \mathrm{C}$ for 24 hours. The fresh and dry weights of the samples were taken using an electronic scale balance. Soil bulk density and moisture content were estimated using Equation (2) and Equation (3) respectively.

$$
B D=M / V
$$

where $B D=$ bulk density, $M=$ mass of oven dry soil $(\mathrm{g})$, and $V=$ volume of core $\left(\mathrm{cm}^{3}\right)$.

$$
\operatorname{MC}(\%)=100(f w-d w) / d w
$$

where $M C(\%)=$ soil moisture content in percentage, $f w=$ fresh weight $(\mathrm{g}), d w=$ dry weight $(\mathrm{g})$.

Soil Organic Carbon ( $S O C$ ) concentration was estimated using the conversion Equation (4) and SOM was estimated using Equation (5) (Wairiu \& Lal, 2003).

$$
\operatorname{SOC}\left(\mathrm{t} \mathrm{C} \mathrm{ha}^{-1}\right)=C(\%) \times \rho \times V
$$

where: $C \%$ is the weight percentage of carbon in the soil depth, $\rho$ is the bulk density of the soil in $\mathrm{tm}^{-3}$ and $V$ is the volume $\left(\mathrm{m}^{3}\right)$ of soil per hectare.

$$
S O M=S O C \times 1.78
$$

To estimate the amount of $\mathrm{CO}_{2}$ equivalence $\left(\mathrm{CO}_{2}\right.$ Eq.) held in the soil from the atmosphere, the ratio of $12 \mathrm{~g}$ of $\mathrm{C}: 44 \mathrm{~g}$ of $\mathrm{CO}_{2}$ was used, based on mass of carbon in the molar mass of $\mathrm{CO}_{2}$ (Kum \& Yinda, 2016).

Deterioration index ( $D I)$ was applied according to Equation (6) (Awotoye et al., 2011) to compute the rate of deterioration of the farmland soil properties compared to that of grazing and forest lands.

$$
D I=\hat{X}-X_{i} / \hat{X}
$$


where: $\hat{X}=$ mean value of soil property in grazing land or forest land, while $X_{i}$ $=$ mean value of soil property in farmland.

\subsection{Statistical Analysis}

Results from the laboratory were all keyed into Microsoft Excel 2016 and computed into secondary parameters (mean, standard deviation and standard error) to facilitate comparison between soil properties. These parameters were imported to SPSS 20 and R statistical packages to test for significant differences, compute boxplots and other inferential statistics. A one-way ANOVA was carried out to test the level of significance between soil properties of the various land uses. Significant differences were assessed at a $p$-value of 0.05 .

\section{Results}

\subsection{Land Use Map and Estimated Surface Areas for Smallholder Farms, Grazing, and Forest Lands}

The land use map derived from the Landsat- 4 data is shown on Figure 2 and the land surface areas of smallholder farmlands, grazing lands, and forest lands are shown on Table 1. The land use types identified on Figure 2 include; smallholder farm-lands, grazing land, forest (mountain forest, valley forest, dense forest, secondary forest), plantation, water bodies, and settlement. Grazing and forest lands each occupy more than a quarter $(27.4 \%$ and $30.74 \%$ respectively) of the entire surface of the $\mathrm{BH}$, while smallholder farms occupy just $4.6 \%$ (Table 1 ).

\subsection{Soil Properties}

The results of soil properties planned in this study are shown on Table 2 and Table 3.

Soil Moisture, Bulk Density, Texture, and $\mathrm{pH}$

Analysis of particle sizes from the laboratory revealed variation in soil texture of the land use types. The soil textures were sandy loam and sandy silt loam (Table 2). Calculations of soil bulk densities revealed slight variations in mean bulk densities of the land use types. Bulk density values ranged from $0.95 \pm 0.04$ (forest) to $1.09 \pm 0.02 \mathrm{~g} / \mathrm{cm}^{3}$ (farms) with a significant difference between them $(\mathrm{F}=4.344, \mathrm{df}=2, p=0.029)$ (Table 3$)$. Mean soil $\mathrm{pH}$ ranged from $4.87 \pm 0.13$ (farmland) to $5.25 \pm 0.21$ (grazing land) with no significant difference between them at 0.05 level (Table 3). Soil moisture content was lowest in smallholder farmlands $(4.97 \% \pm 0.35 \%)$ and highest in forest $(7.34 \% \pm 0.44 \%)$. The soil moisture content of these land uses differs significantly from each other at 0.01 level $(\mathrm{F}=9.108, \mathrm{df}=2, p=0.002)$.

SOC, Total Nitrogen (TN), and Available Phosphorus (Av.P)

Calculating the mean SOC (\%) values from the three land uses revealed highest and lowest mean SOC (\%) values in forest land $(6.03 \% \pm 0.81 \%)$ and smallholder farmland $(4.07 \pm 0.29)$ respectively (Table 3$)$. The mean SOC values sig- 
nificantly differed from each other $(\mathrm{F}=9.754, \mathrm{df}=2, p=0.001)$. SOC values were generally high but factors TN and Av.P are generally low according FAO 2006 guide for integrated nutrient management with significantly differences recorded between them at $\alpha=0.05$ (Table 3). Table 3 also shows the index of deterioration of the soil properties under smallholder farmland use from forest and grazing lands. The deterioration indices were highest for N, SOC and moisture content. Available $\mathrm{P}$, bulk density, and $\mathrm{pH}$ showed negative deterioration indices.

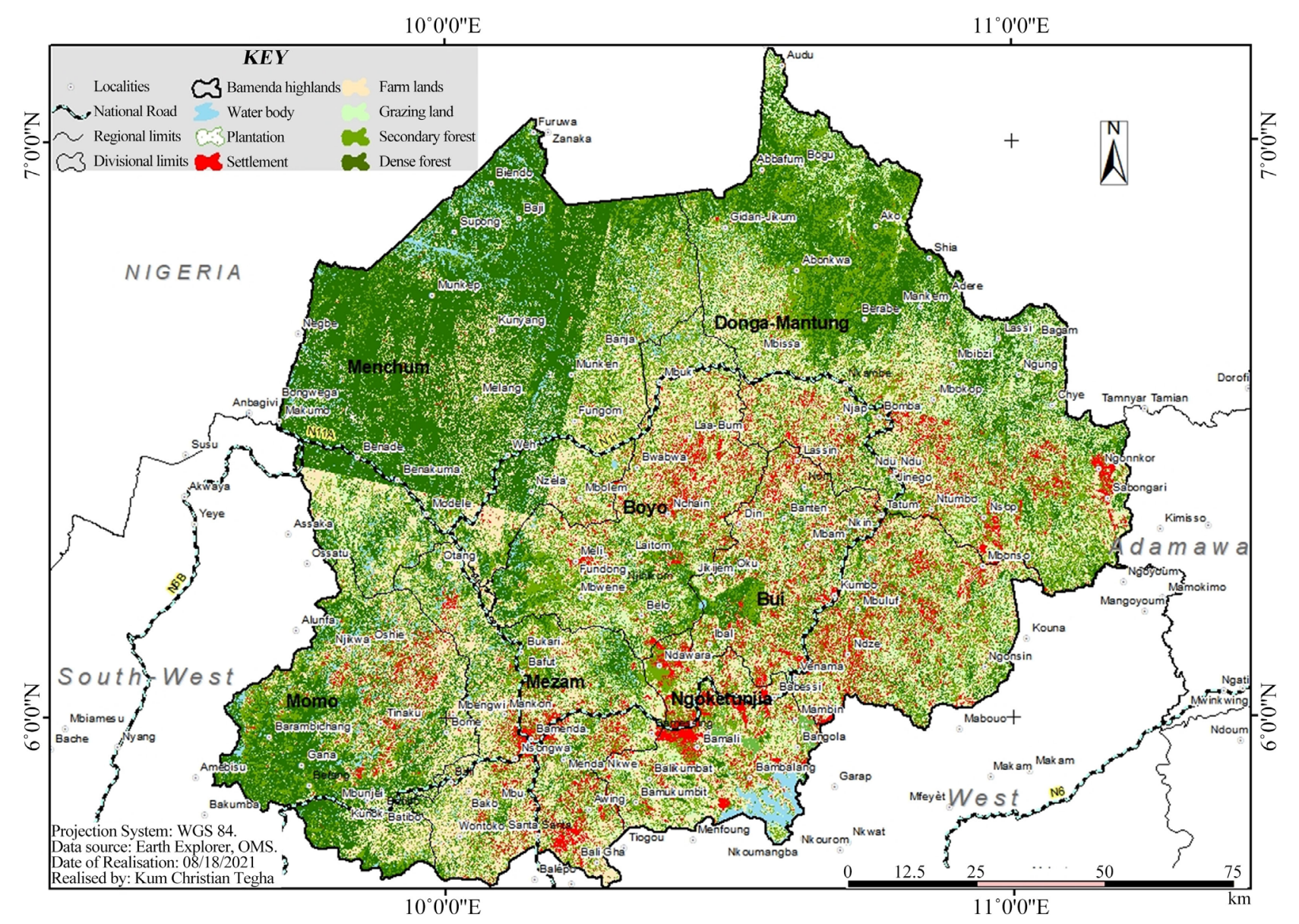

Figure 2. Land use map of the Bamenda Highlands, Cameroon.

Table 1. Estimated surface area of smallholder farmlands, grazing lands and forest lands in the Bamenda Highlands, Cameroon.

\begin{tabular}{cccccc}
\hline \multicolumn{2}{c}{ Grazing Lands } & \multicolumn{2}{c}{ Smallholder Farmlands } & \multicolumn{2}{c}{ Forest Lands } \\
\hline Type of Grazing Land & Surface area (ha) & Types of smallholder farmland & Surface area (ha) & Types of Forest land & Surface area (ha) \\
Woody Grazing land & $62,975.45$ & Pure Farmland & 18.206 .95 & Evergreen Forest & $156,434.35$ \\
Grazing land in cultivated lands & $77,484.11$ & Farmland in forest & $4,986.36$ & Valley Forest & $322,039.39$ \\
Grazing land in forest & $157,146.95$ & Farmland in savannah & $43,807.15$ & Galerie Forest & $10,017.45$ \\
Shrub Grazing land & $179,033.13$ & Farmland in shrubs & $13,719.79$ & Secondary Forest & $45,886.45$ \\
Total & $\mathbf{4 7 6 , 6 7 7 . 5 1}$ & Total & $\mathbf{8 0 , 7 2 0 . 2 4}$ & & $\mathbf{5 3 4 , 8 9 3 . 5 0}$ \\
\hline
\end{tabular}


Table 2. Mean sand, silt, and clay of the three land use systems.

\begin{tabular}{ccccc}
\hline Land use Type & Sand (\%) & Silt (\%) & Clay (\%) & Textural Class \\
\hline Smallholder farmlands & $51.30 \pm 2.52$ & $35.27 \pm 5.44$ & $13.43 \pm 1.34$ & Sandy Loam \\
Grazing land & $40.79 \pm 4.07$ & $44.85 \pm 3.80$ & $14.36 \pm 0.86$ & Sandy Silt Loam \\
Forest & $44.49 \pm 5.80$ & $40.08 \pm 5.35$ & $15.43 \pm 0.81$ & Sandy Silt loam \\
Total & $45.53 \pm 2.66$ & $40.07 \pm .74$ & $14.40 \pm 0.60$ & Sandy Silt Loam \\
\hline
\end{tabular}

Table 3. Mean soil properties (physical and chemical) and deterioration indices.

\begin{tabular}{|c|c|c|c|c|c|c|}
\hline Land Use & MC (\%) & $\mathrm{BD}\left(\mathrm{g} / \mathrm{cm}^{3}\right)$ & $\operatorname{soc}(\%)$ & Total N(g/kg) & Av. P (mg/kg) & $\mathrm{pH}(\mathrm{KCl})$ \\
\hline Smallholder Farmlands & $4.97 \pm 0.35_{\mathrm{a}, \mathrm{b}}$ & $1.09 \pm 0.02_{b}$ & $4.07 \pm 0.29_{\mathrm{a}}$ & $2.33 \pm 0.17 \mathrm{~b}$ & $19.70 \pm 1.94 \mathrm{~b}$ & $4.87 \pm 0.13$ \\
\hline Grazing land & $7.07 \pm 0.49 \mathrm{a}$ & $0.98 \pm 0.04$ & $5.52 \pm 0.37 \mathrm{a}$ & $3.01 \pm 0.32$ & $17.38 \pm 1.00_{\mathrm{b}}$ & $5.25 \pm 0.21$ \\
\hline Forest & $7.34 \pm 0.44_{b}$ & $0.95 \pm 0.04 \mathrm{~b}$ & $6.03 \pm 0.81_{\mathrm{a}}$ & $3.49 \pm 0.24 \mathrm{~b}$ & $15.52 \pm 1.87_{\mathrm{b}}$ & $5.12 \pm 0.15$ \\
\hline Mean \pm SE & $6.46 \pm 0.33$ & $1.01 \pm .02$ & $5.21 \pm 0.26$ & $487.35 \pm 34.77$ & $16.87 \pm 1.07$ & $4.61 \pm 0.09$ \\
\hline \multicolumn{7}{|c|}{ Soil Deterioration Indices } \\
\hline Farmlands (from forest) & 32.29 & -14.74 & 32.50 & 33.24 & -45.71 & -2.18 \\
\hline Farmlands (from Grazing land) & 29.70 & -11.22 & 24.27 & 22.59 & -13.35 & -2.63 \\
\hline
\end{tabular}

Values with the same letter within a column are not significantly different from each other at 0.05 level.

\section{Relationship between Soil Properties}

Results of the relationship between soil properties are shown on Table 4. The results reveal a significant positive correlation between SOC and TN, and SOC and moisture content. Meanwhile significant negative correlations were revealed between SOC and bulk density, SOC and Av.P, TN and bulk density, and nitrogen and phosphorus (Table 4).

\section{Soil Organic Carbon Stocks}

The mean SOC density in $\mathrm{tC} / \mathrm{ha}$ ranged from $132.91 \pm 9.48$ for smallholder farmland-use to $170.37 \pm 9.77$ for forest land-use (Table 5). Estimated amounts of $\mathrm{CO}_{2}$ equivalence from the SOC density values in each land-use type revealed highest mean value of $624.68 \pm 35.80 \mathrm{t} / \mathrm{ha}$ of $\mathrm{CO}_{2}$ equivalence for forest and lowest mean value of $487.35 \pm 34.77 \mathrm{t} / \mathrm{ha}$ of $\mathrm{CO}_{2}$ equivalence for smallholder farms (Table 5). Mean average soil organic matter (SOM) in $t /$ ha for the $0-30 \mathrm{~cm}$ depth for the land-use systems ranged from $236.59 \pm 16.88 \mathrm{t} / \mathrm{ha}$ in smallholder farmland-use to $298.97 \pm 18.09 \mathrm{t} / \mathrm{ha}$ in forest land use (Figure 3).

Total organic carbon (TOC) stocks in mega tonnes (Mt) for $30 \mathrm{~cm}$ depth gave a maximum $91.13 \mathrm{Mt}$ for forest and a minimum of $10.73 \mathrm{Mt}$ for smallholder farms giving a total for the three land uses of $179.41 \mathrm{Mt}$ (Table 5). Comparison of TOC stock (Mt) values for the three land uses using one way ANOVA test, revealed that these TOC stocks values differ significantly from each other at $\alpha=$ $0.05(\mathrm{~F}=8.03, \mathrm{df}=2, p=0.015)($ Table 5$)$. 
Table 4. Pearson's Correlations between soil properties.

\begin{tabular}{|c|c|c|c|c|c|c|}
\hline & SOC (\%) & Bulk D $\left(\mathrm{g} / \mathrm{cm}^{3}\right)$ & Total N (g/kg) & Av. P (mg/kg) & $\mathrm{pH}(\mathrm{KCl})$ & Moisture (\%) \\
\hline SOC (\%) & 1 & & & & & \\
\hline Bulk D $\left(\mathrm{g} / \mathrm{cm}^{3}\right)$ & $-0.559^{* *}$ & 1 & & & & \\
\hline Total N (g/kg) & $0.920^{* *}$ & $-0.645^{* *}$ & 1 & & & \\
\hline Av. P (mg/kg) & $-0.672^{* *}$ & $0.396 \mathrm{~ns}$ & $-0.623^{* *}$ & 1 & & \\
\hline $\mathrm{pH}(\mathrm{KCl})$ & $0.119 \mathrm{~ns}$ & $0.154 \mathrm{~ns}$ & $0.033 \mathrm{~ns}$ & $-0.158 \mathrm{~ns}$ & 1 & \\
\hline Moisture (\%) & $0.521^{*}$ & $-0.387 \mathrm{~ns}$ & $0.427 \mathrm{~ns}$ & $-0.425 \mathrm{~ns}$ & $0.046 \mathrm{~ns}$ & 1 \\
\hline
\end{tabular}

${ }^{* *}$ Correlation is significant at the 0.01 level (2-tailed), ${ }^{*}$ Correlation is significant at the 0.05 level (2-tailed) ns Correlation is not significant at the 0.05 level (2-tailed).

Table 5. Comparison of SOC Stocks (within $30 \mathrm{~cm}$ depth) in the three LUS of the BH.

\begin{tabular}{cccccc}
\hline Land Use & Estimated surface area $($ ha $)$ & SOC $($ tC/ha) & CO $_{2}$ Eq. of SOC $($ t/ha $)$ & TOC-Stocks $($ Mt $)$ & CO $E q$. of TOC $($ Mt $)$ \\
\hline Smallholder Farmlands & $80,720.24$ & $132.91 \pm 9.48^{*}$ & $487.35 \pm 34.77^{*}$ & $10.73^{*}$ & 39.34 \\
Grazing Lands & $476,677.51$ & $162.68 \pm 11.98^{*}$ & $596.48 \pm 36.72^{*}$ & $77.55^{*}$ & 285.25 \\
Forest lands & $534,893.50$ & $170.37 \pm 9.77^{*}$ & $624.68 \pm 35.80^{*}$ & $91.13^{*}$ & 334.14 \\
Total/Mean & $\mathbf{1 , 0 9 2 , 2 9 1 . 2 5}$ & $\mathbf{1 5 5 . 3 2}$ & $\mathbf{5 6 9 . 4 9}$ & $\mathbf{1 7 9 . 4 1}$ & $\mathbf{6 5 9 . 7 3}$ \\
\hline
\end{tabular}

* The mean values differ significantly at 0.05 level.

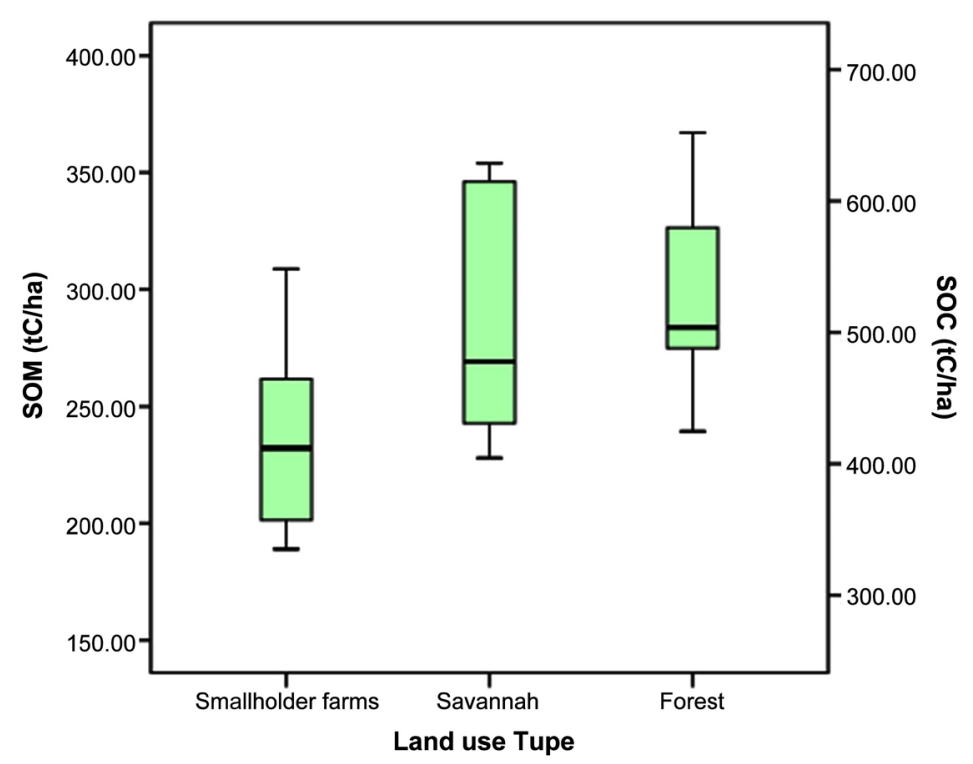

Figure 3. Box plot showing the SOM values in $\mathrm{t} /$ ha derived from SOC (tC/ha).

\section{Discussions}

\subsection{Land Use Map and Estimated Surface Areas for Smallholder Farms, Savannah and Forest}

The three land uses identified in this study including forest (natural or afforested), grazing land, and smallholder farmlands agrees with those identified by Tellen and Yerima (2018) in some selected sites of the BH. The forest land here 
is comprised of native trees and shrubs while the grazing lands are made of short grasses. Tellen and Yerima, 2018, and Azinwi et al., 2018 both described the vegetation of the $\mathrm{BH}$ as savannah zone dominated by short grasses and deciduous shrubs. This description is proven right by the results on Table 1 and Figure 2 which shows dominance in forest and savannah land area from other land uses. The area of smallholder farms is just about $5 \%$ of the total surface area of the $\mathrm{BH}$, but the effects of the tillage practices on this area should not be minimized. Results from census studies of 2005 and 2015 shows an increase in population density of 100 persons $/ \mathrm{km}^{2}$ to 114 persons $/ \mathrm{km}^{2}$ in just 10 years. This increase in population will only result to more increase in smallholder farmlands at the expense of grazing and forest lands.

\subsection{Soil Properties}

\section{Soil Moisture, Bulk Density, Texture, and $p H$}

Results on Table 2 indicate that sand is the primary soil particle among the three land uses in the $\mathrm{BH}$, and the lowest sand content of $40.79 \pm 4.07$ occurred in the grazing LU. This could be due to different effects of soil erosion control in each of the LUS. The conversion of forest/grazing land into farmland is known to deteriorate soil texture and making the land more susceptible to erosion due to soil structure disturbance. This result is in harmony with Kum and Yinda (2016) who also recorded different soil texture types for different land uses.

The results revealed higher $\mathrm{BD}$ in smallholder farms $>$ Grazing land $>$ forest with significant differences between BDs of farmlands and forest. This is in accord with the works of Sahani and Jiao et al. (2020), who also recorded higher $\mathrm{BD}$ in arable lands. The higher $\mathrm{BD}$ in smallholder farms could result from the combined influence of the ploughing in tillage layer, roots distribution, repeated sowing and harvesting, and human activities on the farm. These factors may lead to soil compaction resulting to higher $\mathrm{BD}$.

In this study, variation in soil moisture content occurred among the three land uses, the lower moisture content observed in farmlands was likely related to the complete tillage ridge formation with no surface cover and irrigation. This leads to easy evaporation of soil moisture. Moisture content between forest and grazing land LUS had no significant difference between them but the higher MC in forest could be due to more surface cover by leave litter (Jiao et al., 2020).

The $\mathrm{pH}$ (4.87 to 5.25) across the three land use types was homogenous and showed moderate acidity in accordance with the Kum and Yinda, (2016) who also revealed homogenous and moderate acidity $\mathrm{pH}$ values in different land use type at the southern parts of the Mount Cameroon National Park (MCNP). The lower $\mathrm{pH}$ value in farmland can be attributed to the use of chemicals by some smallholder farmers in the $\mathrm{BH}$ to preserve soil fertility.

SOC, Total Nitrogen (TN), and Available Phosphorus (Av.P)

The SOC that ranged from $4.07 \%$ to $6.03 \%$ are slightly more than the results of Tellen and Yerima (2018), which stood at $2.77 \%$ to $4.73 \%$ SOC on the North 
West Region of Cameroon. The higher values in this study are probably due to fact that Tellen and Yerima (2018) cover only two of the 7 microclimatic zones of the $\mathrm{BH}$ during their sample collection. Also, some of the smallholder farms in this study had gone through a fallow period of 2 - 3 years before recultivation unlike the continuous cultivation farms in Tellen and Yerima (2018). Soil fertility values (SOC and total N) were highest in forest, grazing land, and farmland in that order with significant differences recorded between the values at $p<0.05$ (Table 3). Higher SOC and TN in forest are probably due to the high accumulation and decay of leaf litter and roots within the forest than grazing land and farmlands in accordance with Tellen \& Yerima, (2018) and Kum and Yinda (2016). Lower SOC and TN in the farmlands could be due to soil exposure and lack of understory vegetation which leaves the soil vulnerable to erosion that washes away topsoil nutrients (Boley et al., 2009). Phosphorus values from the soils of these land use types were slightly above the critical value for phosphorus in soils (around $15 \mathrm{mg} / \mathrm{kg}$ for Bray-II), indicating the good soil quality of the zone and making the area suitable for agriculture. The significantly higher mean Av.P in farm lands use than forest and grazing land uses are probably due to application of fertilizers. This agrees with the results of Shrestha et al. (2007) who attributed higher values of Phosphorus in Bari soils to application of fertilizers.

The results of soil deterioration index revealed that MC, SOC, and TN of farmland soils are the most deteriorated properties from forest and grazing lands. The higher BD value in farmlands signifies deterioration. Higher Av.P and $\mathrm{pH}$ values in farmlands signify soil improvement probably resulting from farm management practices.

\section{Relationship between Soil Properties}

Significant correlations $(p<0.05)$ were recorded between soil physicochemical properties (Table 4). SOC correlated positively with the total nitrogen $(\mathrm{r}=$ $0.920)$, and moisture content $(r=0.521)$ indicating that an increase in the SOC also increases soil's total nitrogen and moisture. Moisture content is important for the determination of mineralization rates and conservation of SOM in the soils. Nitrogen is a macro plant nutrient whose availability in soil increases with increase SOC (Okeke, 2014). SOC negatively correlated with BD, Av.P suggesting that an increase in SOC decreases BD and Av.P and vice versa. This result is in agreement with Jiao et al. (2020) who also found negative correlations between SOC and BD. Land use practices and inputs can change the dynamic of soil properties yielding some of these negative relationships. Results on Table 4 clearly show that there exists a relationship between the soil physicochemical properties which affects the availability of nutrients.

\section{Soil Organic Carbon Stocks}

Soil carbon density which is key to total SOC stock estimation ranged from $132.91 \pm 9.48$ (farmlands) to $170.37 \pm 9.77 \mathrm{tC} / \mathrm{ha}$ (forest). These results were found to be higher than those of Nasi et al. (2009) from various ecosystems in the Congo basin ranging 35 to 82 t/ha. This higher SOC stock could be the result 
of humic ferralsols, rich in SOC and suitable for agriculture. LU can change the function of soils from a carbon source to a carbon sink and vice versa (Zhang \& Shangguan, 2016). Results of this study found that SOC density, SOM, and TOC stock were the highest in forest land, possibly due to input of litter on the surface soil. While the smallholder farmland with little or no litter, frequent disturbance and strong soil respiration in the surface, may have enhanced SOC consumption in the top $30 \mathrm{~cm}$ soil rendering farmland with lowest SOC values. This is in accordance with Jiao et al. (2020) who also found highest SOC content and stocks in forest land and least in arable land. The significant differences in TOC and SOM observed between the three LUSs are in response to the changes in land use/management practices. Land conversion from forest/grazing lands to smallholder farmlands increases soil mineralisation resulting to SOC decline and, thus, soil degradation (Kum \& Yinda 2016; Lal, 2004). Soils under grazing land follow those under forest in SOC stocks as expected because high plant species diversity in grazing land is known to enhance SOC (FAO, 2001) due to diversity in residue that decays directly into the soil.

\section{Conclusion}

Soil MC, BD, and texture play an important role in SOC formation and transformation during land-use and/or land-cover changes. This study revealed robust changes in these soil physical properties and SOC, and TN among the smallholder farmlands, grazing and forest lands. The potential ability to sequester SOC was in the order: forest lands > grazing lands > smallholder farmlands. This trend reflects the current management practice. Most forest lands are either protected or inaccessible with little human activities resulting in much litter accumulation and degradation to SOC. Grazing lands are affected by seasonal grazing activities leading to a reduction in litter accumulation. Smallholder farmlands are completely exposed to air for easy conversion of SOC to $\mathrm{CO}_{2}$. Smallholder farmlands are therefore detrimental to SOC sequestration and possibly contribute significant amounts to rising levels of atmospheric $\mathrm{CO}_{2}$. The $\mathrm{CO}_{2}$ equivalence held by soils of these land-use types follows the same order as SOC, with forest lands having the highest value and smallholder farmlands the least. The significant differences in TOC-stocks between forest/grazing lands and smallholder farmlands prove that forest/grazing-land conservation is important and needed, if the fight against climate change is to be confronted. This therefore gives additional impetus for the protection of forest lands in the $\mathrm{BH}$. Therefore, the long-term conventional cultivation of smallholder farmlands is not favorable to SOC management. More attention should be tailored to improving the soil quality in smallholder farmlands.

This research was aimed at setting a baseline for total SOC stocks in the $\mathrm{BH}$, which is necessary for future SOC stock modelling and estimation of carbon sequestration potential of various land use systems in the area. In Cameroon, a national SOC database is not available and this could hinder the country's access to 
funds from the Clean Development Mechanism (CDM) as proposed under article 12 of the Kyoto Protocol of the UNFCCC. This local level total SOC stocks estimation should serve as a starting point for large scale modelling/estimations of past and future SOC stocks and provide some accuracy for a national SOC data.

\section{Authors' Contributions}

KCT literature review, field survey, data collection and analysis and manuscript preparation and submissions. TAS overall management of the field survey, technical support and reviewing the manuscript, NM/TC technical support and reviewing the manuscript. All authors read and approved the final manuscript.

\section{Acknowledgements}

The authors acknowledge all the support from the staff and students of the Department of Agricultural and Environmental Engineering, College of Technology, the University of Bamenda for the varied contributions towards this work. Also, we acknowledge the financial support from the Cameroon Ministry of Higher Education through the Research Modernisation Allowance.

\section{Declaration}

This research article is written by the authors whose names have been appropriately indicated.

\section{Ethics Approval and Consent to Participate}

The authors hereby declare that; this manuscript has not been published or considered for publication elsewhere.

\section{Conflicts of Interest}

The authors declare no conflicts of interest regarding the publication of this paper.

\section{References}

Awotoye, O., Ogunkun, C. O., \& Adeniyi, S. A. (2011). Assessment of Soil Quality under Various Land Use Practices in a Humid Agro-Ecological Zone of Nigeria. African Journal Plant Sciences, 5, 565-569.

Azinwi, T. P., Temgoua, E., Wotchoko, P., Boukong, A., \& Bitom, D. (2018). Soil Properties and Land Capability Evaluation in a Mountainous Ecosystem of North-West Cameroon. Journal of Geoscience and Environment Protection, 6, 15-33. https://doi.org/10.4236/gep.2018.67002

Battle, M., Bender, M., Sowers, T., Tans, P. P., Butler, J. H., Elkins, J. W., Ellis, J. T., Conway, T., Zhang, N., Lang, P., \& Clarket, A. D. (1996). Atmospheric Gas Concentrations over the Past Century Measured in Air from Firn at the South Pole. Nature, 383, 231-235. https://doi.org/10.1038/383231a0

Boley, D. J., Drew, A. P., \& Andrus, R. E. (2009). Effects of Active Pasture, Teak (Tectona grandis) and Mixed Native Plantations on Soil Chemistry in Costa Rica. Forest Ecology 
Management, 257, 2254-2261. https://doi.org/10.1016/j.foreco.2009.02.035

Bremner, J. M., \& Mulvaney, C. S. (1982). Total Nitrogen. In D. R. Buxton (Ed.), Methods of Soil Analysis, Part 2 (pp. 595-624). American Society of Agronomy Inc. and SSSA Inc.

Cookson, W., Osman, M., Marschner, P., Abaye, D., Clark, I., \& Murphy, D. (2007). Controls on Soil Nitrogen Cycling and Microbial Community Composition across Land Use and Incubation Temperature. Soil Biology and Biochemistry, 39, 744-756. https://doi.org/10.1016/j.soilbio.2006.09.022

FAO (2001). Soil Carbon Sequestration for Improved Land Management (p. 96). World Soil Resources Report.

FAO (2006). Guidelines for Soil Description, a Framework for International Classification, Correlation and Communication (4th ed.).

FAO (2011). Linking Sustainability and Climate Financing: Implications for Agriculture.

Godfray, C. J., Beddington, J. R., Crute, I. R., Haddad, L., Lawrence, D., Muir, J. F., Pretty, J., Robinson, S., Thomas, S. M., \& Toulmin, C. (2011). Food Security: The Challenge of Feeding 9 Billion People. Science, 327, 812-816.

https://doi.org/10.1126/science. 1185383

IPCC (2001). Third Assessment Report 2001. Cambridge University Press.

Jiao, S. Y., Li, J. R., Li, Y. Q., Xu, Z. Y., Kong, B. S., Li, Y., \& Shen, Y. W. (2020). Variation of Soil Organic Carbon and Physical Properties in Relation to Land Uses in the Yellow River Delta, China. Scientific Reports, 10, Article No. 20317.

https://doi.org/10.1038/s41598-020-77303-8

Kum, C. T., \& Yinda, G. S. (2016). Soil Organic Carbon Stocks in Mount Cameroon National Park under Different Land Uses. Journal of Ecology and the Natural Environment, 8, 20-30.

Lal, R. (2004). Soil Carbon Sequestration to Mitigate Climate Change. Geoderma, 123, 1-22. https://doi.org/10.1016/j.geoderma.2004.01.032

Li, C., Frolking, S., Crocker, G. J., Grace, P. R., Klir, J., Korcdhens, M., \& Poulton, P. R. (1997). Simulating Trends in Soil Organic Carbon in Long-Term Experiments Using the DNDC Model. Geoderma, 81, 45-60. https://doi.org/10.1016/S0016-7061(97)00080-3

Manu, I. N., U, W. N., Tarla, D. N., \& Agharih, W. N. (2014). Causes of Cattle Theft in the North West Region of Cameroon. Scholarly Journal of Agricultural Science, 4, 181-187.

McLean, E. O. (1982). Soil pH and Lime Requirement. In D. R. Buxton (Ed.), Methods of Soil Analysis, Part 2 (pp. 199-224). American Society of Agronomy Inc. and SSSA Inc. https://doi.org/10.2134/agronmonogr9.2.2ed.c12

MINADER (2015). The State of Biodiversity for Food and Agriculture in the Republic of Cameroon.

Nasi, R., Mayaux, P., Devers, D., Bayol, N., Eba'a Atyi, R., Mugnier, A., Cassagne, B., Billand, A., \& Sonwa, D. J. (2009). Un apercu des stocks de carbone et leurs variations dans les forêts du Bassin du Congo (pp. 199-216). Office des publications de l'Union Européenne.

Ndoh, M., Innocent, B. D., \& Balgah, R. (2016). Climate Variability and Change in the Bamenda Highlands of North Western Cameroon: Perceptions, Impacts and Coping Mechanisms. British Journal of Applied Science \& Technology, 12, 1-18. https://doi.org/10.9734/BJAST/2016/21818

Okeke, P. N. (2014). Impact of Solid Waste on Physico-Chemical Properties Ferreal Soil 
in Owerri, Nigeria. An International Multidisciplinary Journal, Ethiopia, 3, 118-120. https://doi.org/10.4314/afrrev.v8i3.10

Olsen, S. R., \& Sommers, L. E. (1980). Phosphorus. In A. L. Page, R. H. Buxton, \& K. D. R. Miller (Eds.), Methods of Soil Analysis (pp. 403-430). American Society of Agronomy. https://doi.org/10.2134/agronmonogr9.2.2ed.c24

Roe, D., Nelson, F., \& Sandbrook, C. (2009). Community Management of Natural Resources in Africa: Impacts, Experiences and Future Directions. Natural Resource Issues No. 18, International Institute for Environment and Development.

Schiavon, M., Perringanier, C., \& Portal, J. M. (1995). The Pollution of Water by Pesticides-State and Origin. Agronomie, 15, 157-170. https://doi.org/10.1051/agro:19950301

Shrestha, B. M., Singh, B. R., Sitaula, B. K., Lal, R., \& Bajracharya, R. M. (2007). Soil Aggregate- and Particle-Associated Organic Carbon under Different Land Uses in Nepal. Soil Science Society America Journal, 71, 1194-1203.

https://doi.org/10.2136/sssaj2006.0405

Tellen, V. A., \& Yerima, B. P. K. (2018). Effects of Land Use Change on Soil Physicochemical Properties in Selected Areas in the North West Region of Cameroon. Environmental Systems Research, 7, 3. https://doi.org/10.1186/s40068-018-0106-0

Tume, S. J. P., Zetem, C., Nulah, S., Ndzifoin, A., Mbuh, B., Nyuyfoni, S., Ahfembombi, L., \& Kwei, J. (2020). Climate Change and Food Security in the Bamenda Highlands of Cameroon. In V. Squires, \& M. Gaur (Eds.), Food Security and Land Use Change under Conditions of Climatic Variability (pp. 107-124). Springer. https://doi.org/10.1007/978-3-030-36762-6 6

Vermeulen, S. J., Campbell, B. M., \& Ingram, J. S. I. (2012). Climate Change and Food Systems. Annual Review of Environmental Resources, 37, 195-222. https://doi.org/10.1146/annurev-environ-020411-130608

Wairiu, M., \& Lal, R. (2003). Soil Organic Carbon in Relation to Cultivation and Topsoil Removal on Sloping Lands of Kolombangara, Solomon Islands. Soil Tillage Resource, 70, 19-27. https://doi.org/10.1016/S0167-1987(02)00116-2

Walkey, A. J., \& Black, I. A. (1934). Estimation of Soil Organic Carbon by the Chromic Acid Titration Method. Soil Science, 37, 29-38. https://doi.org/10.1097/00010694-193401000-00003

Watson, R. T., Zinyowera, M. C., \& Moss, R. H. (1996). Climate Change 1995: Impacts, Adaptations and Mitigation of Climate Change: Scientific-Technical Analyses. Cambridge University Press.

WDR (2007). Development and the Next Generation. The World Bank.

Yao, M. K., Angui, P. K. T., Konaté, S., Tondoh, J. E., Tano, Y., Abbadie, L., \& Benest, D. (2010). Effects of Land Use Types on Soil Organic Carbon and Nitrogen Dynamics in Mid-West Cote d'Ivoire. European Journal Scientific Research, 40, 211-222.

Yerima, B. P. K., \& Van Ranst, E. (2005). Major Soil Classification System Used in the Tropics: Soils of Cameroon. Trafford Publication.

Zhang, Y. W., \& Shangguan, Z. P. (2016). The Coupling Interaction of Soil Water and Organic Carbon Storage in the Long Vegetation Restoration on the Loess Plateau. Ecological Engineering, 91, 574-581. https://doi.org/10.1016/j.ecoleng.2016.03.033 